European Journal of Accounting, Auditing and Finance Research

Vol.8, No.2, pp.20-37, February 2020

Published by ECRTD-UK

Print ISSN: 2053-4086(Print), Online ISSN: 2053-4094(Online)

\title{
THE IMPACT OF LIQUIDITY ON BANK PROFITABILITY: CASE OF TUNISIA
}

\author{
Dr Mohamed Aymen Ben Moussa ${ }^{(1)}$ Adel boubaker ${ }^{(2)}$
}

(1) PhD Finance,Faculty of Economics sciences and Management of Tunis, University el Manar

(2) Professor in Finance, Faculty of Economis sciences and Management of Tunis

\begin{abstract}
Liquidity and profitability are two important variables in the banking industry. In this article, we studied. The impact of liquidity on bank profitability in the Tunisian context. We used a sample of 18 banks over the period (2000...2017). We employ 2 models of panel static in the empirical research. We found that (liquid assets / total assets) and (total credits / total deposits) have a positive and significant impact on return on assets (ROA) whereas (current assets / current liabilities) have not significant impact on ROA. Also, we found that (liquid assets / total assets), and (total credits / total deposits) have a negative and significant impact on ROE (return on equity). Whereas (current assets / current liabilities) have not significant impact on ROE.
\end{abstract}

KEYWORDS: liquidity, profitability, bank, panel

\section{1-INTRODUCTION}

Liquidity creation is the primary function of bank but also a major source of vulnerability. The vulnerability form their primary function requires deliberate policies and actions by the bank to mitigate against such risks ( Dybvig ( 1983), Bryant (1980)).A bank is liquid when it is capable of meeting its own obligation when they become due, repay deposit and to make such payment on customer order ( Lartey and al ( 2013), BIS ( 2009)). Liquidity can be defined as the assets or securities which can be easily convertible into cash . Liquidity refers to the short term assets ( Cash , short term, advances , and balance with other bank ) and short term liabilities ( short term borrowing, account payable , lending to financial institutions , and short term deposit ) ( Achraf and al 2017).Liquidity management is essential for bank effectiveness and profitability. On the other hand, profitability means a situation where revenues exceeds expenses and which allow bank to generate profits ( Bawacha (2018)) .It is important to determine the relationship between liquidity and profitability ( Sile and al (2019) , Ibrahim ( 2017), Ferrouhi ( 2014), Shachera ( 2012), Awlo and al ( 2019) ,Mazrova ( 2015).Indeed, we attempt to study the impact of liquidity on bank profitability in Tunisian context. We will use approach that consists of 3 sections. First, we will show the literature review, and then we will analyze the empirical study. At the end, we will make the conclusion.

\section{LITERATURE REVIEW}

\section{Liquidity}

\section{A-Concept of bank liquidity}

Bank liquidity means the ability of the bank to maintain sufficient funds to pays for its maturing obligations .Nwaezecku ( 2008) defined liquidity as the degree of convertibility to cash or the ease which any asset be converted to cash hold at a fair market price . A bank is 
liquid when it is capable of meeting its own obligations when they become due, repay deposits and to make such payment based on customer order (Lartey and al 2013; BIS 2009) Alshatti(2015) argues that liquidity is the ability of banks to meet the financial needs of their increased assets and meeting ability as when they fall due without the occurrence of unforeseen losses. For commercial banks ,Adalestinsson ( 2014) points out the liquidity can be achieved through 3 different ways, the first are is the sale of assets, the second way is to borrow money from credits in financial markets, and the third way is relied on the repayment of debts from debtors .

\section{B-Anticipated income theory}

According to Sobyibo( 2014), the anticipated theory of liquidity particularly focuses on long term advances. According to this theory, regardless of the nature and character of a borrower's business, the bank plan the liquidation of the term loan from the anticipated income of the borrower. A term loan is for a period exceeding one year and extending to less than 5 years .

\section{C-Shiftability theory}

In accordance to Alshatti( 2016), the shiftability theory is a process by which bank interchange or exchange its assets for the extreme liquid when there is pancity of liquidity . Shiftability is an approach to keep bank liquidity supporting the shiftability of assets. When a bank is short of ready money, it is able to sale or repo its assets to be a more liquid bank.

\section{D-Commercial loan theory}

This theory states that whenever commercial banks make short term self-liquidating productive loans, the central bank should lend to the banks on the security of such short term loans .

\section{E-The trade-off theory}

This states that there is opportunity cost for a bank either pursuing to be liquid or profitable. Under this theory, banks that choose to be liquid will not be profitable and vice versa. As the tow fundamental goals cannot be achieved together, for banks to be solvent and maintain to institute an efficient financial management practices that will balance the liquidity and profitability trade-off so that banks can be optimally liquid and profitable. The major argument against this theory isthat is based on banks' ability to make profit on granting substantial part of its liquid resources as loan from which it can earn interest income . ( Kajola and al (2019).

\section{F-liquidity regulation}

Liquidity plays a significant role in the sustainable development of bank and the stability of financial system, strict liquidity regulation are supposed to put forward to guard against problems due to the lack of liquidity ( Bawacha (2018) ).

Rochet ( 2008) indicates 2 reasons for liquidity regulation, from micro-point of view , liquidity regulation from prevent bankruptcy and damage of depositors interest by regulation liquidity buffers of banks, from macro-point of view, liquidity regulation help maintenance of financial system ability .

The 2008 global financial crisis reminded financial institutions to that of liquidity risk on financial system . 
European Journal of Accounting, Auditing and Finance Research

Vol.8, No.2, pp.20-37, February 2020

Published by ECRTD-UK

Print ISSN: 2053-4086(Print), Online ISSN: 2053-4094(Online)

Basel III focused on liquidity by introducing liquidity coverage ratio and net stable funding ( LCR), ratio ( NSFR) .

LCR = high quality assets / 30 days net cash outflows NSFR= Available stable funding / required stable funding

NSFR( net stable funding ratio ) measures the bank ability to get access to stable funding, this ratio comes out to make sure banks have available the stable funding with 1 year period . ( Bawacha ( 2018)).

\section{Bank profitability}

Like all business, bank profit by earning more money throw what they pay in expenses, the major position of a bank profit comes from fees that it charges for its services and the interest that it earns on its assets.

Profitability maximization is the ultimate goal for banks because of their for profit essence. Two aspects are concerned with profitability, the revenues generated and the cost. Thus, the away of improving, profitability includes enhancing revenues and minimizing costs.

The profitability of banking sector is important with to aim to estimate the constancy and reliability of the financial and banking industry (Albertazzi and Gambacorta 2009). The profitability is represented by 3 alternatives variables ( Kabejeh and al 2012). First, most important profitability ratio is ROA, also ROE. The next is the return on investment ( ROI), it measures the bank's efficiency by using invested capital. Earnings per share serve as a pointer of bank's profitability (Pearce and al 1987).

\section{The relationship between bank liquidity and bank profitability}

There are many researches that studies the relationship between bank liquidity and bank profitability.Shachera( 2012) studied listed banks in Iran for the period ( 2002...2009) . He found that liquidity has significant impact on bank profitability .Warrad and al (2015) studied 15 Jordanian banks listed at Amman Stock exchange (ASE). They found significant impact of liquidity (quickratio ) on ROA ( Return on assets ). Nishanthini and Merrajancy(2015) studied a sample of banks in Sirilanka over the period $(2008 \ldots 2012)$. We found that liquidity have not significant impact on bank profitability.

Vodova( 2016) studied the impact of liquidity on profitability of the polish banking industry over the period ( 2007...2013) . He found that liquidity has a negative impact on bank profitability .Also Abulaila ,Alhathlool ( 2016) studied banks in Saudia . They found no significant relationship between liquidity and bank profitability .Salim and Bilal ( 2016) studied 4 commercial banks in Oman for the period (2010...2014). They found significant relationship between bank liquidity and bank profitability.Moreover, Mebounon and al ( 2016) examined 38 banks in WAEMU region for the period ( 2001...2011). They found a non linearrelationship between bank liquidity and bank profitability .Also Achraf and al (2017) studied 10 banks in Pakistan for the period ( 2006...2015). They found that quick ratio has a negative impact on bank profitability, whereas cash and current ratio has a positive impact on bank profitability .

Also Ibrahim ( 2017) examined the influence of liquidity on the profitability of Iraqi banks over the period ( 2005...2013) . He found a significant impact of liquidity on bank profitability. 
Hakimi and Zaghdoudi( 2017) studied a sample of 10 Tunisian banks over the period ( $1990 \ldots 2013$ ) . They found that liquidity (measured by total credits / total deposits) has a negative effect on bank profitability ( NIM) .Munithi and Waweru ( 2017) studied 41 commercial of banks in Kenya . They measured liquidity by liquidity coverage ratio ( LCR) and net stable funding ratio ( NSFR) while profitability is measured by ROE ( return on equity). Panel data techniques of random effect estimation and generalized method of moments were used to purge time invariant observed specific effect and to mitigate potential endoegneityproblems. Findings indicate that NSFR is negatively associated with bank profitability both in long run and short run while LCR does not significantly influence the profitability of commercial banks in long run and short run .

Charmler and al (2018) studied a sample of 21 banks in Ghana over the period ( 2007...2016). They found that liquidity is positively associated with bank profitability .Moreover, Lucy and al (2018) studied a 5 banks in Nigeria for the period (2007...2016). They found that liquidity has positive and significant effect on bank profitability .On the other hand,Bawacha( 2018) studied a sample of 50 banks in Asia, Europe, North America . The findings of this study that only DAR (deposit to assets ratio) significantly impact on profitability (Return on equity )

Moreover Mohanty and Mehrota ( 2018) studied 27 public sector banks and 20 private sector banks in India for the period ( 2011-2012) and ( 2015-2016). They found that there is a negative effect of cash deposit ratio and investment deposit ratio on ROA. But there is no significant effect of liquidity on ROE .Ghurtskaia and Lemonjava (2018) indicated that the relationship is positive between liquidity and bank profitability in the Georgian context.

Also Awlo and al (2019) studied the impact of liquidity on bank profitability in Ethiopia over the period ( 1986...2017) . Autoregressive distributed lag model ( ARDL) is used to investigate the short run and long run effect of liquidity on profitability .Current ratio and loan to deposit ratio of the bank were used to measure liquidity while ROA is dependent variable ( measure of profitability ). They found that loan to deposit ratio negatively affect return on assets in the long run, while current ratio significantly and positively affects ROA in the long run .Sahyouni and wang ( 2019) estimated the amount liquidity created by Syrian banks between ( 2004---2010) and further investigates the effect of liquidity creation on bank performance, controlling for set a bank level, industry level, and macroeconomic variables .The findings show that bank liquidity creation improved during the prewar period and showed positive figure, but started to decline sharply during wartime .Besides Sile and al ( 2019) studied 43 commercial banks in Kenya over the period ( 2012...2016). They found that there is a negative relationship between liquidity and profitability .

\section{Empirical study}

The relationship between bank liquidity and bank profitability has been the object of several studies prompting us to study this problematic in the Tunisian context .

Under this section, we will identify the sample at the beginning and then we specify the variables and the model .

After we carry out the necessary econometric tests . Finally we show the estimation results of the model and their interpretations . 
European Journal of Accounting, Auditing and Finance Research

Vol.8, No.2, pp.20-37, February 2020

Published by ECRTD-UK

Print ISSN: 2053-4086(Print), Online ISSN: 2053-4094(Online)

\section{Sample}

We will use 11 banks(BIAT, STB, BNA, BH, ATB, Amen Bank, BH , BTEI, BT ,Atttijari bank ,UBCI) that belong to professional association of banks in Tunisian over the period ( 2000---2017) . Financial data are collected through the annual reports of banks existed in the web site of the professional association of banks in Tunisia over the period ( 2000----2017).

\section{Estimation method}

We will utilize panel static because it controls :

-The time and individual variation in the observable behavior or cross sectional times series aggregated

-The observed or unobserved individual heterogeneity

\section{Specification of variables}

We will estimate the following models :

ROA $\mathbf{i}, \mathrm{t}=$ b0+b1 Sizei,t + b2. CAPi,t +b3.TLAi,t+b4. CEAi,t +b5 CFCi,t +b6. Tdepositi,t $+$

+b7 CEAi,t + b8 CFCi,t +b9 Tdepositi,t + b 10.TPIBi,t +b 11.TINFi,t + Ei,t

ROEi,t $=$ b0+b1 Sizei,t +b2.CAPi,t +b3. TLAi,t +b4. ALAi,t +b5. CDi,t +b6.CRi,t +b7.

CEAi,t +b8. CFCi,t +b9. Tdepositi,t +b10. TPIBi,t +b11. TINFi,t +Ei,t

Where :

$\mathrm{i}=$ bank

$\mathrm{t}=$ time

bo $=$ constant

b1, b2, b3, b4, b5, b6, b7, b8 , b9 ,b10, b11:Parameters to be estimated

ROA $=$ return on assets $=$ net income $/$ total assets

ROA shows how to generate income from the assets of the bank ( Chin 2011). It measures the profit earned per dollars of assets and reflect how well bank management uses the bank's investment resources to generate profits ( Naceur 2003). ROA is considered as the best proxy of profit ( Flamini and al (2009), Samad (2005)).

$\mathrm{ROE}=$ return on equity $=$ net income $/$ total equity

ROE reflects the ability of bank to use its own funds to generate profits ( Yilmaz 2013)

This ratio shows the profit earned per 1 dinar of investment. This is an indicator of how well bank uses investor's money or generate profits .( Chouikh, Blagui ( 2017)).

Size $=$ size of the bank $=$ natural logarithm of total assets

Size can show the economies of scale. The large banks benefit from economies of scale which reduces the cost of production and information gathering (Boyd, Runkhle (1993)) .

\section{ALA $=$ liquid assets / total assets}

ALA depicts the bank's ability to absorb the liquidity shocks. In theory the higher liquidity ratio indicates that the bank is better position to meet its stochastic withdrawals ( Chagwiza (2014)) . 
European Journal of Accounting, Auditing and Finance Research

Vol.8, No.2, pp.20-37, February 2020

Published by ECRTD-UK

Print ISSN: 2053-4086(Print), Online ISSN: 2053-4094(Online)

\section{CEA = operating expenses / Total assets}

Operating expenses including personal expenses and other expenses. CEA shows the weight of operating expenses compared to total assets

\section{CFC $=$ Financial expenses $/$ total credits}

Financial expenses include interest expense due to loan made in the money market and the capital market by banks. CFC shows the share of financial expenses in relation to total credits

\section{$T$ deposit $=$ total deposits $/$ total assets}

Deposit include demands deposits and term deposits. T deposit show the share of deposits compared to total assets. The more the deposits a bank collect, the more the loan opportunities, it will be able to generate further profit ( Mencucci , Paolucci (2016)).

\section{$C D=$ total credits / total deposits}

It is the ratio that describes how allocation of funds in term de deposits, comparing to a number of funds which is obtained from saving ( Widyastuti and al (2017)). When this ratio is higher, it show more risky conditions because the funds from deposits have been collected in more of credit .Conversely the lower ratio indicate effective banks in lending decisions .

\section{TPIB = Growth rate of gross domestic product}

TPIB show the growth in the economy activity in the country .Ayadi ,Boujelbene ( 2012), Asarkaya , Ozcan ( 2007) pointed out the when economic growth increase, the banks make more profit .

\section{$\mathbf{C R}=$ current assets / current liabilities}

This is the proportion of bank's current assets to its current liabilities . It shows the strength of the bank in meeting the short term maturing obligations to the claimant of those obligations .(Kajola and al ( 2019).

\section{TLA = total credits / total assets}

Bank loans are the main course of return and are anticipated to impact positively the profits ( Menicucci , Paolucci ( 2016))

\section{CAP $=$ total equity / total assets}

The capital strength of bank indicates its capacity to meet deposit demand and sends signals to bank customers about its stability and ability to protect their savings especially during periods of uncertainty such as the financial crisis (Ghosh 2016; Berger (1995).It is largely assumed that well capitalized banks challenge lower probable cost of financial distress and such circumstances will then be turned into high profitability ( Abreu, Mendes ( 2002).

\section{TINF $=$ rate of inflation}

TINF shows the rate of increase in the price index. Inflation is generally the persistence increase of price level of goods and services .

We test the following hypotheses :

\section{H1: (Liquid assets / total assets) have a positive impact on ROA}


Print ISSN: 2053-4086(Print), Online ISSN: 2053-4094(Online)

H2: (Total credits/ total deposits) have a positive and significant impact on ROA

H3 (Liquid assets / total assets) have a negative and significant impact on ROE

H4: (Total credits / total deposits) have a negative and significant impact on ROE

H5: (Current assets / current liabilities) have a significant impact on ROA

H6: (Current assets / Current liabilities) have a significant impact on ROE

\section{Analysis of descriptive statistics}

Table 1 :Descriptive statistics

\begin{tabular}{|l|l|l|l|l|l|}
\hline Variable & Observation & Mean & $\begin{array}{l}\text { Standard } \\
\text { deviation }\end{array}$ & Minimum & Maximum \\
\hline ROA & 198 & 0.011424 & 0.01439 & 0 & 0.1291 \\
\hline ROE & 198 & 0.08746 & 0.088 & 0 & 0.9572 \\
\hline CAP & 198 & 0.1626 & 0.1705 & 0 & 0.97724 \\
\hline Size & 198 & 14.058 & 1.329 & 10.19 & 16.46 \\
\hline TLA & 198 & 0.7165 & 0.1910 & 0.024 & 0.97 \\
\hline ALA & 198 & 0.037 & 0.04055 & 0.0033 & 0.44 \\
\hline CEA & 198 & 0.026 & 0.02132 & 0.0023 & 0.3614 \\
\hline CFC & 198 & 0.0324 & 0.0206 & 0.001788 & 0.3179 \\
\hline Tdeposit & 198 & 0.6545 & 0.2626 & 0.0066 & 0.9813 \\
\hline TPIB & 198 & 0.03295 & 0.0405 & -0.015 & 0.0611 \\
\hline TINF & 198 & 0.041 & 0.0089 & 0.03 & 0.0715 \\
\hline CD & 198 & 3.57 & 9.50 & 0.16 & 86.032 \\
\hline CR & 198 & 1.11 & 1.51 & 0.074 & 20.20 \\
\hline
\end{tabular}

$198=11 * 18=$ total number of observations

$18=$ Number of years $(2000 \ldots 2017)$

$11=$ Number of banks

ROA ( mean $=0.0114$ ). The net income represent on average $1.14 \%$ of total assets

ROE ( mean $=0.087$ ). The net income represent on average $8.7 \%$ of total equity

Size ( mean $=14.058)$. Most banks have a small and medium size . There is no large variation in size of banks

CAP $($ mean $=0.1626)$. The equity represent on average $16.26 \%$ of total assets .

But there is a large variation in capital between banks. Standard deviation $=17.05 \%$

TLA $($ mean $=71.65 \%)$. Total credit represent on average $71.65 \%$ of total assets . The standard deviation is high ( 19.210)

ALA $($ mean $=0.037)$. Liquid assets represent on average $3.7 \%$ of total assets

The standard deviation is low $=0.04$

CEA $($ mean $=0.026)$. Operating expenses represent on average $2.6 \%$ of total assets . Standard deviation is low ( 0.021)

CFC $($ mean $=0.0324)$. Financial expenses represent on average $3.24 \%$ of total credits . Standard deviation is low $=2.6 \%$

There isn't a big difference between banks in term of financial expenses .

$\mathrm{T}$ deposit $($ mean $=0.6545)$. Total deposit represent on average $65.45 \%$ of total assets . The standard deviation is high $26 \%$. There is a big difference between banks in term of deposits . TPIB ( mean $=3.29 \%$ ). The economic growth is not good . It is negative in 2011 because of revolution . 
Print ISSN: 2053-4086(Print), Online ISSN: 2053-4094(Online)

TINF ( mean $=4.1 \%$ ). The rate of inflation is acceptable . Standard deviation is not high . There is not big difference between years but after revolution of 2011 this rate will be high . CD ( mean $=3.75)$ In average, total credits represent 3.75 of total deposit, it is a great standard deviation between banks .

CR $($ mean $=1.11)$. In average , current assets represent 1.11 current liabilities .

The difference is big in term of CR between banks . ( Standard deviation $=20.20)$ is high .

Econometric tests

A-Mutlicolineraity test

Table 2 Correlation between variables

\begin{tabular}{|l|l|l|l|l|l|l|}
\hline & ROA & ROE & Size & CAP & TLA & CEA \\
\hline ROA & 1.000 & & & & & \\
\hline ROE & 0.2220 & 1.000 & & & & \\
\hline Size & -0.0874 & 0.3293 & 1.000 & & & \\
\hline CAP & 0.4551 & -0.1262 & -0.4699 & 1.000 & & \\
\hline TLA & -0.1706 & -0.0100 & 0.2604 & -0.0917 & 1.000 & \\
\hline CEA & -0.0289 & 0.0674 & 0.1122 & -0.0612 & -0.07 & 1.000 \\
\hline CFC & -0.0911 & 0.0589 & 0.0369 & -0.0848 & -0.1739 & 0.2536 \\
\hline Tdeposit & -0.02323 & 0.2107 & 0.4532 & -0.56 & -0.0841 & 0.1771 \\
\hline ALA & 0.0256 & -0.1174 & -0.1656 & 0.1179 & -0.057 & -0.0716 \\
\hline CD & 0.0359 & -0.1540 & -0.2526 & 0.1069 & 0.1123 & -0.22 \\
\hline CR & -0.0617 & -0.1461 & -0.26 & 0.1134 & -0.0725 & -0.0526 \\
\hline TPIB & 0.1370 & -0.1069 & -0.2207 & 0.1836 & -0.23 & -0.068 \\
\hline TINF & -0.1149 & 0.0963 & 0.24 & -0.242 & 0.1986 & -0.0792 \\
\hline
\end{tabular}

Table 3 Suite of correlation between variables

\begin{tabular}{|l|l|l|l|l|l|l|l|}
\hline & CFC & $\begin{array}{l}\text { T } \\
\text { deposit }\end{array}$ & ALA & CD & CR & TPIB & TINF \\
\hline CFC & 1.000 & & & & & & \\
\hline Tdeposit & 0.2661 & 1.000 & & & & & \\
\hline ALA & -0.0031 & -0.24 & 1.000 & & & & \\
\hline CD & -0.2912 & -0.6041 & 0.0942 & 1.000 & & & \\
\hline CR & 0.0111 & -0.2749 & 0.187 & 0.2281 & 1.000 & & \\
\hline TPIB & 0.0161 & -0.12 & 0.15561 & 0.0955 & 0.1367 & 1.000 & \\
\hline TINF & -0.06 & 0.1958 & -0.1743 & -0.0433 & -0.15 & 0.0090 & 1.000 \\
\hline
\end{tabular}


European Journal of Accounting, Auditing and Finance Research

Vol.8, No.2, pp.20-37, February 2020

Published by ECRTD-UK

Print ISSN: 2053-4086(Print), Online ISSN: 2053-4094(Online)

There is no problem of multicolinearity because all coefficients are inferior to $80 \%$

Table3 :VIF values

\begin{tabular}{|l|l|}
\hline Variable & VIF \\
\hline Size & 1.58 \\
\hline T deposit & 2.97 \\
\hline CAP & 1.94 \\
\hline ROA & 0.59 \\
\hline ROE & 0.63 \\
\hline CEA & 1.12 \\
\hline CFC & 1.19 \\
\hline ALA & 1.24 \\
\hline CD & 1.94 \\
\hline CR & 1.28 \\
\hline TPIB & 1.14 \\
\hline TLA & 1.22 \\
\hline TINF & 1.17 \\
\hline
\end{tabular}

VIF is defined as the factor by which the variance of estimator is inflated in the presence of vary high multicolinearity (Masiero, Nicolan ( 2012)). If the VIF value of independent variable is greater than 10 , that variable should be excluded in order to overcome multicolinearity ( Shah (2011)) .

\section{B-Hausman test}

Hausman test determines if the individual effects are fixed or random. It determines if the coefficient Beta are fixed or random effect are not statistically different . Under the null hypothesis of independence between errors and explanatory variables, both estimators are unbiaised . So the estimated become somewhatdifferent .

The random effect model assumes that the relationship between the dependent variable and the explanatory variable is not fixed but a random, the individual effect is not fixed parameter but a random variable. ( Bourbonnais 2009) .

According to Wooldridge ( 2009), if the prob value of Hausman is statistically significant ( $p$ inferior to 0.05). Fixed effect will be better, other wise random effect

In our research, $\mathrm{p}$ value of model $1=0.9732, \mathrm{P}$ value of model $2=0.3498$

$\mathrm{P}$ value is superior to $10 \%$, we choose random effect for regression of 2 models because it is more pertinent .

\section{C-Breush Pagan test}

It has been assumed that the variance of the error is constant. This is known as the assumption of homosedasticity. If the errors not have a constant variance, they are said to be heterosedastic (Amene, Alenu (2019)). The test statistic is X 2 with the degree of freedom . It tests the null hypothesis of homoscedasticity. If the chi squared value is significant with $p$ value below an appropriate $\mathrm{p}$ inferior to 0.05 . Then the null hypothesis of homoscedasticity is rejected and heteroscedasticity is assumed. 
Print ISSN: 2053-4086(Print), Online ISSN: 2053-4094(Online)

Results of estimations and interpretations

Table 3: Results of estimation of model 1

\begin{tabular}{|l|l|l|l|l|}
\hline ROA & Coefficient & $\mathbf{Z}$ & P value & Standard error \\
\hline Size & 0.0019 & 1.83 & 0.067 & 0.0019 \\
\hline CAP & 0.0375 & $5.31^{* *}$ & 0.000 & 0.0307 \\
\hline TLA & -0.0081 & $-2.03^{* *}$ & 0.043 & -0.0081 \\
\hline CEA & -0.032 & -1.03 & 0.304 & -0.032 \\
\hline CFC & -0.062 & -1.82 & 0.069 & -0.062 \\
\hline Tdeposit & -0.0053 & -1.05 & 0.294 & -0.0053 \\
\hline ALA & 0.0047 & $2.26^{* *}$ & 0.0597 & 0.0057 \\
\hline CD & 0.0000743 & $2.77^{* * *}$ & 0.0139 & 0.096 \\
\hline CR & -0.0006673 & -1.39 & 0.165 & 0.0075 \\
\hline TPIB & 0.0631 & $2.54^{* * *}$ & 0.0106 & 0.084 \\
\hline TINF & -0.074 & $-2.91^{* * *}$ & 0.0143 & 0.0925 \\
\hline Cons & -0.0071 & -0.48 & 0.629 & 0.0149 \\
\hline
\end{tabular}

The relationship between ROA and size is positive ( if size increase by $1 \%$, ROA will be increase by $0.0019 \%$ ). The increase of size has a positive effect on return on assets . This result is similar to be found by ( Serwadda( 2018), Jasnad , Lahsan ( 2018), Menicucci , Paolucci( 2016), Secrezi ( 2015), Sahyouni and Wang ( 2019) ), but contrary to found by ( Pasiouras , Kosmidou ( 2007), Athansoglou and al (2008), Shah and Khan (2017)).

Large banks can benefit from economies of scale enable cost reduction (Molyneux, Thornton ( 1992), Bikker, Hu( 2002), Goddard and al (2004)). Larger banks might also benefit from economies of scope economies (reduced risks and product diversification ), by accessing to markets in which small banks cannot enter ( Menicucci , Paolucci ( 2016).

Also , the relationship between ROA and CAP is positive (if CAP increase by $1 \%$, ROA will be increase by $0.0375 \%$ ). The increase of capital has a positive effect on return on assets . This result is similar to found by ( JaraBartin at al ( 2014), Acaravci , Claim ( 2013), Kosmidou , Pasiouras ( 2005), Abel , LaRose ( 2016), Sarwadda ( 2018), Trujillo , Ponce ( 2013) , Clamentina , Isu ( 2013), Menicucci , Paolucci ( 2016), Widyastuti and al ( 2017),Dhouibi (2017), Amen, Alemu ( 2019). But contrary to found by ( Secrezi 2015), Lwa and Zogli (2017).

A high volume of equity will reduce the cost of capital, causing a positive effect on profitability Furthermore, it is estimated that banks with higher capital ratio are less dependent on external funding, with a positive impact on bank profit . Therefore, well capitalized banks achieve greater profitability because lower risk raises bank's worthiness and reduces the cost of funding ( Menicucci and Paolucci 2016).

The relationship between ROA and TLA is negative ( if TLA increase by 1\%, ROA will be increase by $0.0081 \%$ ). The increase of total credits in term of total assets has a negative effect on return on assets. This relationship is significant at $1 \%$. This result is similar to found by ( Hassan, Bashir ( 2005), Staikouras and Wood ( 2004) ) but contrary to found by ( Menicucci , Paloucci ( 2016) . The increase of loan volume along with lower margins, it could be presumed a negative effect on bank profitability.Moreover, the relationship between CEA and ROA is negative ( if CEA increase by $1 \%$, ROA will be increased by $0.032 \%$ ). The increase 
of operational costs has a negative effect on return on assets. This result is similar to found by ( Serwadda ( 2018), Athansoglou and al ( 2008), Kosmidou and al ( 2005), Purkuoko , Sudiyatno ( 2013). The negative effect of cost means that there is a lack of competence in expense management since banks pass part of increased costs to customer and the remaining part to profits , possibly due to the fact that competition does not allow them to overcharge ( Athansoglou and al (2008)) . The relationship between CFC and ROA is negative (if CFC increase by $1 \%$, ROA will be decrease by $0.062 \%$ ). The increase of financial expenses has a negative effect on return on assets.

Also the relationship between $\mathrm{T}$ deposit and ROA is negative (if $\mathrm{T}$ deposit increase by $1 \%$, ROA will be decrease by $0.053 \%$ ). The increase of $\mathrm{T}$ deposits in term of assets has a negative effect on return on assets. This result is similar to found by ( Shah, Khan (2017)). The relationship between ALA and ROA is positive ( if ALA increase by 1\%, ROA will be increase by $0.0047 \%$ ). The increase of liquid assets has a positive effect on return on assets .

This result is similar to found by ( Abel , Le Rouse ( 2016)) , Jawad , Lahsen ( 2018),Charmler and al (2018). A good liquidity ratio reduces the risk of failure that may lower the financing cost and hence increases profitability ( Alexiou, Sofoklis ( 2009)) . On the other hand, the relationship between $\mathrm{CD}$ and ROA is positive ( if CA increase by $1 \%$, ROA will be increaseby $0.00000743 \%$ ). The increase of total credits in term of total deposits has a positive effect on return on assets .

It is similar to result found by ( Hassan , Bashir ( 2003) , Sufian , Habibullah ( 2009), Margareth , Zein ( 2013),Ibrahim ( 2017), Bawacha ( 2018)) but contrary to result found by ( Sabir , and al ( 2012), Purwoko, Sudyatno ( 2013), Aini ( 2013). The relationship between $\mathrm{CR}$ and ROA is negative (if CR increase by $1 \%$, ROA will be decrease by $0.000673 \%$ ) . The increase of (current assets / current liabilities ) has a negative effect on return on assets . This result is contrary to found by ( Waleed and al (2016), Ashraf and al (2017), Ibrahim and Aqeel ( 2017)) .

Besides, the relationship between TPIB and ROA is positive (if TPIB increase by 1\%, ROA will be increase by $0.0031 \%$ ). The increase of economic growth has a positive effect on return on assets. This result is similar to found by ( Turjillo -Ponce ( 2013), Dietrich , Wanzenried ( 2011), Jawad, Lahsan ( 2018), Calza et al ( 2006), Sahyouni and Wang ( 2019), but contrary to result found by ( Blagui ,Chouikh ( 2017), Dhouibi (2015), Lwa , Zogli ( 2017), Amene, Alemu ( 2019).

The relationship between TINF and ROA is negative ( if TINF increase by $1 \%$, ROA will be decrease by $0.074 \%)$. The increase of inflation has a negative effect on return on assets .This result is similar to found by ( Ben Naceur ( 2003), Ghazouani ( 2005), Umar and al (2014), Boyd and al ( 2000), Garcia Herrero and al ( 2009), Izhar ( 2007), Amene, Alemu ( 2009) but contrary to found by ( Turjillo Ponce ( 2013), Clementina and al ( 2014), Chouikh, Blaghui ( 2017), Dhouibi (2015). 
European Journal of Accounting, Auditing and Finance Research

Vol.8, No.2, pp.20-37, February 2020

Published by ECRTD-UK

Print ISSN: 2053-4086(Print), Online ISSN: 2053-4094(Online)

Table4 Results of estimation of model 2

\begin{tabular}{|l|l|l|l|l|}
\hline ROE & Coefficient & $\mathbf{Z}$ & Pvalue & Standard error \\
\hline Size & 0.02326 & $3.26^{* * *}$ & 0.001 & 0.0071 \\
\hline CAP & 0.03343 & 0.83 & 0.406 & 0.040 \\
\hline TLA & -0.0199 & -0.71 & 0.477 & 0.027 \\
\hline CEA & -0.0206 & -0.09 & 0.925 & 0.22 \\
\hline CFC & 0.098 & 0.41 & 0.682 & 0.24 \\
\hline Tdeposit & -0.042 & -1.21 & 0.228 & 0.035 \\
\hline ALA & -0.022 & $-2.17 *$ & 0.1173 & 0.014 \\
\hline CD & -0.0002868 & $-2.43^{* *}$ & 0.0668 & 0.00068 \\
\hline CR & -0.0007973 & -0.24 & 0.812 & 0.036 \\
\hline TPIB & 0.3181 & -2.12 & 0.425 & 0.29 \\
\hline TINF & 0.5796 & 1.03 & 0.303 & 0.56 \\
\hline Cons & -0.21 & -2.14 & 0.032 & 0.10 \\
\hline
\end{tabular}

$(* * * *)$ significant at $1 \%$

(**) significant at $5 \%$

(*) significant at $10 \%$

-There is a positive relationship between ROE and size ( if size increase by $1 \%$, ROE will be increase by $0.02326 \%$ ). This relationship is significant at $1 \%$. The increase of size has a positive effect on return on assets. This result is similar to found by ( Topak and al (2011), Abobaker ( 2018), Ashraf and al ( 2017), Charmler and al (2018), Bogale ( 2019)) . The increase of size can increase bank profitability due to economies of scale .Moreover there is a positive relationship between CAP and ROE ( if CAP increase by $1 \%$, ROE will be increase by $0.033 \%$ ). The increase of CAP has a positive effect on bank return on equity. This result is similar to found by ( Abobaker ( 2018), Athansoglou and al (2008), Ben Naceur ( 2003), Charmler and al (2018) ). Banks with a high capital ratio are considered to be insured against bankruptcy, to have access to cheap funds, to be more flexible in pursuing business opportunities and to have the ability to absorb any unexpected loans ( Al Harbi ( 2019) .

Garcia Herrero and al (2009) suggested that the degree of capitalization could affect the profitability of bank through 4 main channels. Firstly, high levels of capital may raise profitability through an increase in the share of loans. Secondly, high capitalization positively influences credit worthiness. Thirdly, a well capitalized bank will reduce their cost of funding through a reduction in borrowing .Lastly, banks with a greater value of franchise value will have adequate capital .

Besides, there is a negative relationship between TLA and ROE ( if TLA increase by $1 \%$, ROE will be decrease by $0.0199 \%$ ). The increase of total credit in total assets has a negative effect on bank return on equity. This result is similar to result found by ( Anarfi and al ( 2018), Yukel and al (2018)). Therefore, higher level of loans means a possible deterioration of the bank asset quality with a negative effect on bank profitability ( Alper , Anbar ( 2011).On the other hand, there is a negative relationship between CEA and ROE ( if CEA increase by $1 \%$, ROE will be decrease by $0.0206 \%$ ). The increase of operating costs has a negative impact on bank return on equity. Also there is a positive relationship between CFC and ROE ( if CFC increase by $1 \%$, ROE will be increase by $0.098 \%$ ) . 
The increase of financial expenses has a positive effect on bank return on equity .There is a negative relationship between ALA and ROE (if ALA increase by 1\%, ROE will be decrease by $0.022 \%$ ). The increase of liquid assets has a negative effect on return on equity. This result is similar to found by Sile and al (2019) but contrary to result found by Charmler and al ( 2018) .There is a negative relationship between CD and ROE ( if CD increase by $1 \%$, ROE will be decrease by $0.0002868 \%$ ). The increase of ( total credits / total deposits ) has a negative effect on return on equity . This result is contrary to found by Bawacha( 2018), Tamunoski ( 2017) .

There is a negative relationship between $\mathrm{CR}$ and $\mathrm{ROE}$ (if $\mathrm{CR}$ increase by $1 \%$, ROE will be decrease by $0.0007979 \%$ ). The increase of( current assets / current liabilities ) has a negative effect on return on equity. This result is similar to found by Ashraf and al (2017) but contrary to found by Waleed and al (2016), Ibrahim and Aqeel ( 2017), Akinuwum and al ( 2017) .Moreover the relationship between TPIB and ROE is positive ( if TPIB increase by $1 \%$, ROE will be increase by $0.3181 \%$ ). The increase of economic growth has a positive effect on bank return on equity . This relationship is statistically significant at $1 \%$.

This result is similar to found by Zampara and al ( 2018). According to Staikouras, Wood ( 2003), Alexiou, Voyozas ( 2009), Grow and al (2014), Dietrich , Wanzenried ( 2011), a higher GDP growth rate result in higher demand for bank services, on the one hand and lower loan default probability in the other hand. Whereas banks can also impose higher fees and interest for their services resulting in higher profitability (Zampara and al (2018)) . Besides, Karinzadek and al (2013), Said, Tumim ( 2011) argue that GDP growth has a positive effect on the expectation of both the bank and the customers, implying hence that during economic booms not only customers demand for new loans and financial crises but simultaneously banks are also more eager to increase loan supply .

There is a positive relationship between TINF and ROE ( if TINF increase by $1 \%$, ROE will be increase by $0.5796 \%$ ). The increase of inflation has a positive effect on return on equity . This result is similar to result found by ( Rani , Zergaw ( 2017), Naceur, Abdollah ( 2015), Tan , Floros ( 2012), Flamini and al ( 2009), Gul and al (2011), Sufian, Habibullah ( 2009) , Hasanov and al ( 2018), Ben Moussa , Hdidar ( 2019) .But contrary to opinions to result found by Sfyari ( 2012), Boyd and Champ ( 2003). Inflation affect bank performance as it transfers money from services and investors to debtors. Therefore the opportunity cost of holding currency in the future may discourage savings that will in turn affect the performance of bank .

\section{CONCLUSION}

Profitability and liquidity are powerful tools that are useful for efficient and effective financial intermediation as the two variables depict the strength of the banking sector (kajola at al 2019). Also Liquidity means the ability to finance the increase in assets and meet liabilities when they due fall without any unexpected losses, and so the efficient management of liquidity in the bank helps to make sure that the bank is able to make sure that the bank is able to meet the incurred cash, which are usually uncertain and subject to external factors and to the behavior of other agents. The liquidity management is a key factor in business operations 
. It is vital for the survival of business, the firm should have sufficient of liquidity .( Malik and Aqeel 2017) .

In this article, we studied the impact of liquidity on bank profitability in Tunisian context . We choose 18 banks for the period ( 2000...2017). By estimating 2 models of panel static, we found that(liquid assets / total assets) , (total credit / total deposits) have significant and positive impact on ROA ( return on assets ) whereas (currents assets / currents liabilities )have not significant impact on ROA . Also (liquid assets / total assets) ,(total credits / total deposits )have negative and significant impact on $\operatorname{ROE}$ ( return on equity ) whereas (current assets / current liabilities )have not significant impact on ROE .

\section{References}

-Abreu .M , Mendes .V ( 2002) " Commercial bank interest margin and profitability : Evidence from some EU countries " www.iefs.org .uk

-Abulaila .M , J.Alhathlool ( 2016) " The balance between liquidity and profitability in commercial banks ( Saudi Arabia) "Research Journal of Finance and Accounting, vol $7,6, \mathrm{p} 78-89$

-Albertazzi .U , L .Gambacorta ( 2009) " Bank profitability and the business cycle "'Journal of Financial Stability, vol 5 , issue 4 , p 393-409

-Alexiou .C ,Sofoklis.V ( 2009) "'Determinants of bank profitability : Evidence from the Greek banking sector "' Economic Annals , 54, 182, p 93-118

-AlHarbi .A ( 2019) "The determinants of conventional bank profitability in developing and undeveloped OIC countries " Journal of Economics, Finance and Administrative Science, vol 24, $17, \mathrm{p}$ 4-28

-Alshatti .A.S ( 2016) " Determinants of bank profitability : the case of Jordan " Investment Management and Financial Innovations, vol 13, issue 1, p84-91

-Alshatti .A.S ( 2015) " The effect of the liquidity management on profitability in the Jordanian commercial banks " International Journal of Business and Management, vol $10,1, \mathrm{p} 62-71$

-Anarfi .D , E.J.A .Abakah , E .Boateng ( 2016) "' Determinants of bank profitability in Ghana : New Evidence "Asian Journal of Finance and Accounting, vol 8 , 2 , p 194-204

-Anbar .A ,D.Alper ( 2011) " Bank specific and macroeconomic determinants of commercial bank profitability : Empirical evidence from Turkey "Business and Economics Research Journal, vol 2, 2 , p 139-152

-Asarkaya .Y ,S.Ozcan ( 2007) " Determinants of capital structure in financial institutions: The case of Turkey " Journal of BRSA, banking and financial markets , vol 1, issue 1 , p 91-109

-Ashraf .M , M. Nabeel , S.M.Hussain ( 2017) ' Liquidity management and its impact on bank profitability : A perspective of Pakistan “

-Athansoglou .P , Brissimis .S , N .Delis , Matthaios .D ( 2008) " bank specific, industry specific and macroeconomic determinants of bank profitability " Journal of International Financial Markets, Institutions and Money, vol 18 , 2 , p 121-136, April

Ayadi .N , Y .Boujelbene ( 2012) " The determinants of the profitability of the Tunisian deposit banks " IBIMA publishing

-Awulo .T , A .Alemu .B.W.Chala ( 2019) "' Impact of liquidity on profitability of bank : case of commercial banks of Ethiopia "' Research Journal of Finance and Accounting, vol $10,1, \mathrm{p} 26-34$ 
-Ben Moussa .M.A , Z .Hdidar ( 2019) « Bank profitability and Economic growth : Evidence from Tunisia " European Journal of Economic and Financial Research , Volume 3 , issue 4 , August , p 81-95

-Berger .A ( 1995) "The profit - structure relationship in banking tests of market power and efficient structure hypothesis "'Journal of Money, Credit and Banking, vol 27 , issue 2, p 407-431

-Bikker .J.A , H .Hu ( 2002) " Cyclical patterns in profits, provisioning and lending of banks and procyclicality of the New Basel capital requirements "BNL Quarterly Review , $221, \mathrm{p} 143-175$

-Bogale .Y.W ( 2019) "Factors affecting profitability of banks : Empirical evidence from Ethiopian commercial banks " The Journal of Investment Management , 8, 1, January

-Boyd .J.H ,D.E.Runkle ( 1993) " Size and performance of banking firms : Testing the predictions of theory " Journal of Monetary Economics, vol 31, issue 1, p 47-67

-Boyd .J .H , B.A .Champ( 2003) "' inflation and financial market performance : What we learned in the last 10 years ",

-Bryant .J ( 1980) " A model of reserves, bank runs and deposit insurance " Journal of Banking and Finance, vol 4 , issue 4 , p 335-344

-Bwacha .C.R ,J.Xi ( 2018) " The impact of liquidity on profitability" pdfs .semanticscholar.org

-Chagwiza .W ( 2014) "Zimbabwean commercial banks liquidity and its determinants "' International Journal of Empirical Finance, vol 2 , issue 2, p 52-64

-Charmler .R , A .Musah , E .Akomeah , E.D Gakpetor ( 2018) " The impact of liquidity on performance of commercial banks in Ghana " Academic Journal of Economic Studies , vol $4,4, \mathrm{p}$ 78-90

-Chouikh .A , Y .Blagui ( 2017)', The determinants of bank performance : The case of Tunisian listed banks ' Journal of Finance and Accounting, volume 5, 2 , p 53-60

-Clementina .K , H.O .Isu ( 2013) " The impact of capitalization on bank performance in Nigeria ( 1970-2010) : An assessment " International Review of Management and Business research, September, vol 2 , issue 3, p 643-65

-Dhouibi .R (2015) " Determinants of Tunisian bank profitability " International Journal of Finance and Accounting, vol 4, 6, p324-332

-Diamond .D.W ,P.H.Dybvig ( 1983) " Bank runs, deposit insurance and liquidity " The Journal of Political Economy, vol 91, 3 , June , p 401-419

-Dietrich .A ,G.Wanzenried ( 2011) "' Determinants of bank profitability before and during the crisis : Evidence from Switzerland “Journal of International Financial Market , Institutions and Money, vol 21, issue 3, p 307-327

-Ferrouhi .E.M ( 2014) ' Bank liquidity and financial performance : Evidence from Moroccan Banking industry " Business, Theory, Practice, vol 15, 4 , p 351-361

-Flamini .V ,C.Mc Donald, L .Schumacher ( 2009) “ The determinants of commercial bank profitability in Sub Sahran Africa " imf .org

-Goddard J , P .Molyneux .J , O.S .Wilson ( 2004) " The profitability of European banks : A cross sectional and dynamic panel analysis " The Manchester School, vol 72, 3, June , p 363-381

-Ghosh .A ( 2016) " Banking sector globalization and bank performance : A comparative analysis of low income countries : A comparative analysis of low income countries with emerging markets and advanced economies " Review of development Finance, vol 6 , p 58-70 
-Garcia-Herrero.A , S .Gavila , D .Santabarbara ( 2009) "' What explains the low profitability of chinease banks "'

-Ghurtskaia .K ,G.Lemonjava ( 2018) " A study of relationship between liquidity and profitability in Georgian banking sector "' International Journal of Science and Research, vol 7 , issue 4 , p 1609-1613

-Hassan .M.K , A .H.M.Bashir ( 2005) " Determinants of Islamic bank profitability "'

-Hassan .M.K , Bashir .A.H.M ( 2003) " Determinants of islamic bank profitability " $10^{\text {th }}$ ERF annual conference, Morocco, p 16-18

-Hasanov .F.J , N .Bayrauli , N.AlMusehel ( 2018) " Bank specific and macroeconomic determinants of bank profitability : Evidence from oil development Economy "' International Journal of Financial Studies, September, vol 6, 3, p1-21

-Ibrahim .S.S ( 2017) " The impact of liquidity on profitability in banking sector of Iraq : A case of Iraqi commercial banks " Journal of Finance and Banking studies, vol $6,1, p$ 113-121

-Ibrahim.I., M.Aqeel ( 2017) " Impact of liquidity management on profitability in the Pakistani commercial banks " International Journal of Scientific and Engineering research, vol 8 , issue 7 , July, p 1459-1478

-Jaouad .E , O .Lahsen ( 2018) " Factors affecting bank performance : Empirical Evidence from Morocco " European Scientific Journal , vol 14 , 34 , December , p 255-267

-Kajola .S.O , W.A .Sanayolu , A .Alo , O.J .Ojurongbe ( 2019) "' Liquidity and profitability determinants from Nigerian banking sector " Accounting and Taxation Review, vol 3 , 2 , June , p 1-12

-Kabajeh .M.A.M , S.M.AlNu'aimat , F.N.Dahmash ( 2012) " The relationship between ROA , ROE and ROI ratios with Jordanian insurance public companies market share prices "International Journal of Humanities and Social Science, vol 2 , 11, p 115-120

-Lartey . V .C , S .Antwi , E.K .Boadi ( 2013) " The relationship between liquidity and profitability of listed banks in Ghana " International Journal of Business and Social Sciences, vol 4, 3 , March , p 48-63

-Malik .M.U , Aqeel .M ( 2017) " Impact of liquidity management on profitability of the Pakistani commercial banks " American Based Research Journal, vol 6, issue 11, November

-Marazova .G ( 2015) " Liquidity and bank performance "International Business and Economic Research Journal, May / June, vol 14, 3 . p 453-461

-Mebounon .T .G.C ,M.B.Karau , H.P.Dannon ( 2015) " Liquidity and bank profitability in WAEMU zone : A panel data analysis " Afro -Asian Journal of Finance and Accounting, vol 5, 2, p 113-134

-Mohanty .B ,S.Mehrotra ( 2018) "' The effect of liquidity management on profitability : A comparative analysis of public and private sector banks in India "' THE IUP journal of bank management, vol XIII , 1, p 7-20

-Muriithi .J.G , K.M .Warweru ( 2017) " Liquidity risk and financial performance of commercial banks in Kenya " International Journal of Economics and Finance, vol 9 , $3, \mathrm{p} 256-265$

-Molyneux .P , J .Thornton ( 1992) "Determinants of European bank profitability : A note" Journal of Banking and Finance, vol 16, issue 6, p 1173-1178

-Menicucci .E ,Paolucci .G ( 2016) "The determinants of bank profitability : empirical evidence from European banking sector " Journal of Financial Reporting and Accounting, vol 14, 1, p 86-115 
-Nishanthini .A , J .Meerajancy ( 2015) " Trade off between liquidity and profitability : A comparative study between state banks and private banks in Sirilanka " Research on Humanities and Social Sciences, vol $5,7, \mathrm{p} 78-85$

-Pearce .J.A , Freeman .E.B , Robsinon .R.B ( 1987) " The tenous link between formal strategic planning and performance " Academy of management Review , 12, p 658675

-Rani.D.M.S ,L.N.Zergaw( 2017) " Bank specific and industry specific and macroeconomic determinants of bank profitability in Ethiopia " International Journal of Advanced Research in Management and Social Sciences, vol 6 , issue 3 , p 74-96

-Sabir .M.M , Ali .M , Habbe .A.H ( 2012) " The influence of ratio financial results for banks of Islamic banks and conventional banks in Indonesia ' Journal Analisis, volume 1, 1 , p 79-86

-Sahyouni .A ,M.Wang ( 2019) "' Liquidity creation and bank performance : Evidence from MENA " International Journal of Islamic finance, vol 11, 1, p 27-45

-Salim .B .F.A ,Z.O.Bilal ( 2016) " The impact of liquidity management on financial performance in Omani banking sector " International Journal of Applied Business and Economic Research, vol 14,1 , p 545-565

-Samad .A ( 2005) "' Determinants of bank profitability : Empirical Evidence from Bangladesh commercial banks "International Journal of Financial Research, vol 6 , 3 , p 173-179

-Serwadda .I ( 2018) " Determinants of commercial bank profitability : Evidence from Hungary " ACTA Universitates Agriculture et SilviculturemendelianeBrensis, vol 66 , $5, \mathrm{p} 1325-1340$

-Shahchera .M ( 2012) " The impact of liquidity on Iranian bank profitability " Journal of Money and Economy, vol 7, 1, October , p 139-160

-Sufian .F , M .S .Habibullah ( 2009) "'Bank specific and macroeconomic determinants of bank profitability : Empirical evidence from Chinese banking sector " Frontiers of Economics in China, June, Volume 4, issue 2, p 274-291

-Tan.Y ,C.Floros ( 2012) "' Bank profitability and inflation : the case of China ' Journal of Economic Studies, October

-Topak.M.S ,N.H.Talu ( 2016) " International determinants of bank profitability : Evidence from Turkish banking sector " International Journal of Economic Perspectives, vol 10 , issue $1, \mathrm{p} 37-49$

-Trujillo .A , Ponce ( 2013) " What determines the profitability of banks ? Evidence from Spain" Accounting and Finance, vol 53 , issue 2, June, p 561-586

-Umar .M ,Majana .D , Adamu .M ( 2014) "' Conceptual exposition of the effect of inflation on bank performance "'Journal of World Economic Research, vol 3, 5 ,

-Waleed .A , A .Pasha , A .Akhtar ( 2016) " Exploring the impact of liquidity on profitability : Evidence from banking sector of Pakistan " Journal of Internet Banking and Commerce, vol 21, 3 , December

-Warrad .L ,M.AlNimer , R.AlOmari ( 2015) " The impact of liquidity on Jordanian bank profitability through return on assets " Research Journal of Finance and Accounting, vol 6, 5 , p 25-29

-Widyastuti .U , D.E.S .Purwana , S .Zulaihati ( 2017) " Internal determinants of commercial bank profitability in Indonesia " Mediterranean Journal of Social Sciences , vol 8,3 , May, p 219-223 
European Journal of Accounting, Auditing and Finance Research

Vol.8, No.2, pp.20-37, February 2020

Published by ECRTD-UK

Print ISSN: 2053-4086(Print), Online ISSN: 2053-4094(Online)

-Wooldridge J.M ( 2009) " Introductory Econometrics : A Modern Approach " $5^{\text {th }}$ Edition , South Western Langage Learning

-Yuksel .S , S .Mukhtarov, E.Mammadov , O.Ozari ( 2018) " Determinants of profitability in the banking sector: An analysis of post-Soviet Countries "Economies , 6, 41, p 2-15

-Yilmaz .A.A ( 2013) " Profitability of banking system : Evidence from Emerging markets ", WEI International Academic Conference Proceedings ,

-Zampara .K ,Gianopoulos .M , Koufopoulos .M ( 2017) « Macroeconomic and industry specific determinants of bank profitability " International Journal of Business and Economic Sciences Applied Research , 10, 1 , p 13-22 